\title{
Production process development of Nipa bowl from Nipa palm (Nypa fruticans Wurmb.) waste by using solar dryer cabinet for sustainability of Palian river basin community
}

\author{
Noppadon Podkumnerd a, ${ }^{*}$, Supranee Wunsri ${ }^{\text {a }}$, Sujint Khairin ${ }^{\mathrm{b}}$ \\ a Faculty of Liberal Arts, Rajamangala University of Technology Srivijaya, 1 Ratchadamnoen Nok, Bo Yang, Muang, Songkhla 90000. Thailand \\ b Ban Na Yod Tong Nipa Palm Leaf Handicraft, Kantang District, Trang Province, Thailand \\ * Corresponding author: noppadon.p@rmutsv.ac.th
}

\section{Article history}

Received 23 November 2018

Revised 19 December 2018

Accepted 27 February 2019

Published Online 25 August 2019

\begin{abstract}
The objective of this research was to develop the process for the production of Nipa bowls from Nipa palm (Nypa fruticans Wurmb.) waste by using solar energy. Two types of solar dryer were investigated, (1) solar dryer cabinet (SDC) and (2) solar dryer cabinet coupled with heater (SDCH) and were compared to the traditional sun dryer (SD) method. The results demonstrated that the use of SDCH could reduce the humidity of the Nipa leaves to $15.23 \pm 0.78 \%$ within 2 hours. This result was statistically significant at $95 \%$ confident compared to those results obtained from SDC $(49.91 \pm 0.78 \%)$ and SD $(38.66 \pm 0.21 \%)$. The dried leaves obtained from the three drying methods were tested for bacterial contamination. For SD, the maximum bacteria contamination was 95,000 $\pm 40,414 \mathrm{cfu} /$ piece which was higher than SDC ( $480 \pm 173 \mathrm{cfu} /$ piece) and SDCH $(463 \pm 112 \mathrm{cfu} /$ piece $)$ methods. The SDC and SDCH techniques were implemented at Palian river basin community (Ban Na Yod Tong Nipa Palm Leaf Handicraft) in Wang Won Sub-District, Kantang District,Trang Province, Thailand. These techniques could enhance the drying process of Nipa leaves and thus increase the production of Nipa bowls 3.5 times reducing Nipa waste up to 1.83 tons. The villagers could produce approximately 183,000 bowls/year generating an income of more than 55,800 USD for 60 families.
\end{abstract}

Keywords: Nipa palm, Nipa bowl, solar dryer cabinet, Palian river basin community

(C) 2019 Penerbit UTM Press. All rights reserved

\section{INTRODUCTION}

Scientifically known as Nypa fruticans Wurmb., Nipa is grown abundantly in estuaries body of water and found in most tropical mangrove systems (Ronaldo and Nomalina, 2014; Hossain and Islam, 2015). This palm has a horizontal trunk that grows beneath the ground. The leaves are divided into leaflets and can be extend up to $9 \mathrm{~m}(30 \mathrm{ft})$ in height (Hossain and Islam, 2015). Various parts of the Nipa palm can be utilized for several purposes including for food, fuel, housing, cigarette wrapping, molasses, and wine (Ronaldo and Nomalina, 2014; Hossain and Islam, 2015; Tamunaidua et al., 2013; Okugbo et al., 2012; Carandang et al., 2009).

Trang province is located in the south of Thailand. A large numbers of Nipa palm have grown naturally in this city especially in the area of Palian river basin. Traditionally, local people in this area use the leaves of the Nipa palm to make a variety of basketworks and cigarette wrappers. Particularly, in the process of cigarette wrapping, it causes a huge waste especially the leaves. The production of Nipa palm is a unique traditional wisdom which is continued and passed from generation to generation. Currently, large numbers of families produce Nipa palm products and sell them for their living. In order to preserve this ancestral wisdom for future generations and to sell Nipa palm products, the community enterprise group called "Ban Na Yod Tong Nipa Palm Leaf Handicraft" was established formally. This group delivers the products to be marketed in other cities and earn greater income within the group. In addition, the Tourism Authority of Thailand (TAT) is now promoting a community-based tourism (CBT) project, many tourists come to visit the community and the Nipa palm handmade handicrafts have attracted their interest.
To respond to the current requirement, the demand for Nipa palm products from Ban $\mathrm{Na}$ Yod Tong Nipa Palm Leaf Handicraft has increased dramatically during the last few years. One of the most popular products is a bowl called locally as Timha. This bowl is made from Nipa leaves and is widely used in the green market as a container for beverages and foods. Moreover, together with the concerns about the plastic containers which need many years to degrade, the use of green containers produced from Nipa palm is now more favorable and preferable.

The production process of Nipa bowl consists of six main steps as shown in Fig. 1. The first step, the makers start from cutting the top of Nipa shoots and trimming (Fig. 1-a), then, chopping Nipa shoots and sun-drying the shoots to make them softer (Fig. 1-b), the next step, unfolding and rolling Nipa leaves in a circular motion before drying (Fig. 1-c), and then, drying the circular leaves for 1-2 days (Fig. 1-d), and the last step, bringing the leaves to make Nipa bowls (Fig. 1-e and $1-\mathrm{f})$.

However, the production of this product has not met the demands since the traditional ways of making this local bowl is not effective and time consuming. Each day, an approximately 1,500 - 2,000 pieces of leaves are needed to make 100 Nipa bowls. However, the production is still insufficient for the markets demand as it is limited by the drying steps. It is realized that the drying of Nipa is the bottleneck of the production line. The use of sunlight in the open-air is not suitable as it is very much depended on the climate conditions. Consequently, the leaves are not fully dried resulting in short storage time and high risk of microbial contamination. This conditions will reduce the quality of the products. Thus, the use of advance alternative technology that can enhance drying efficiency is needed. 


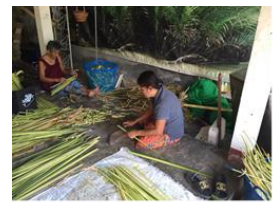

(A)

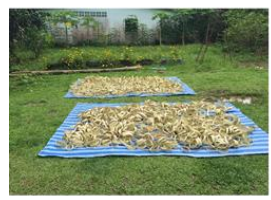

(D)

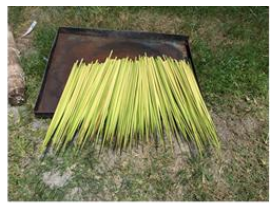

(B)

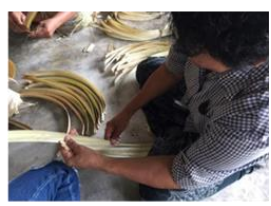

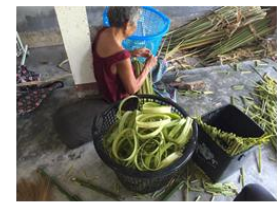

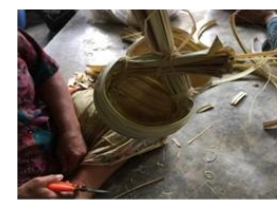

Fig. 1 The production process of Nipa bowl consists of 6 main steps: (A) cutting the top of Nipa shoots and trimming; (B) chopping Nipa shoots and sun-drying; (C) unfolding and rolling Nipa leaves in a circular motion; (D) second drying; (E) making Nipa bowls; and (F) the finished Nipa bowl.

Recently, solar dryers have been widely used for various products. This technology uses indirect solar radiation and the principle is based on the collection of solar energy by heating-up the air volume in solar collectors and conduct the hot air from the collector to an attached enclosure, the drying chamber. There are several classes of dryers; natural and forced convection solar dryers, direct solar dryers, and indirect solar dryers (Belessiotis et al., 2011; Sharma et al., 2009). Previous studies revealed that different solar dryer have been designed (Nambing et al., 2015; Onibogi et al., 2012; Hamdi et al., 2018). For examples, Numbing and Maikasuwa (2015) pioneered and reported the construction of solar fish dryers that are capable of drying a piece of whole fish within a few hours and raise the temperature of the ice fish to about $82^{\circ} \mathrm{C}$ (Nambing et al., 2015). In the same vein, Onigbogi et al. (2012) has constructed a solar dyer that can remove $43.2 \%$ and $40.6 \%$ moisture content in maize and plantain, respectively. The obtained results revealed its ability to dry food items rapidly to acceptable moisture (Onibogi et al., 2012). Based on the results of previous studies, it can be assumed that the use of solar dryer could be utilized for drying Nipa leaves. Applied to this current work, the researcher designed and constructed the solar dryer as a community-based research with association of Ban $\mathrm{Na}$ Yod Tong Nipa Palm Leaf Handicraft in Wang Won Sub-district, Kantang District, Trang Province, Thailand. The heating efficiency, humidity removal, and bacterial contamination control of the solar dryer were studied and reported.

\section{EXPERIMENTAL}

\section{The design of solar dryer cabinets}

The photograph view of the solar dryer cabinet (SDC) is shown in Fig. 2. The dryer was designed as a square shape with a dimension of $1.0 \mathrm{~m} \times 2.0 \mathrm{~m} \times 2.0 \mathrm{~m}$. The volume of the dryer was $4.0 \mathrm{~m}^{3}$. The structure was made from metal (1") and covered with transparent polycarbonate sheet. For SDCH, two heaters $(2,000 \mathrm{~W})$ were installed at the corners of the cabinet. The fans were installed on the top of the cabinet that were run by solar cells $(10 \mathrm{~W})$.

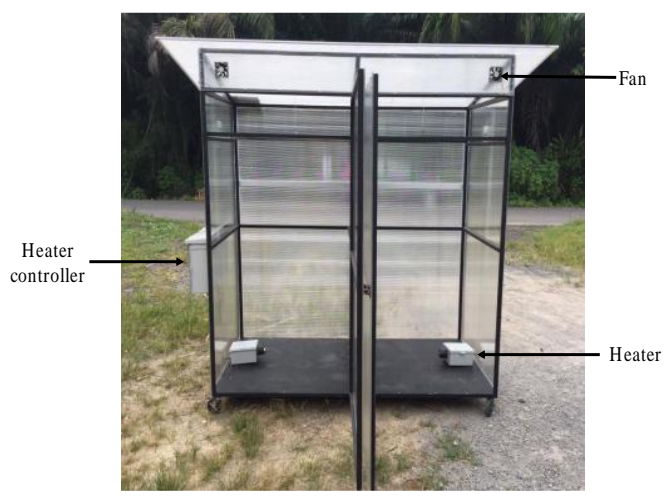

Fig. 2 The solar dryer cabinet.

\section{The production of Nipa leaves using solar dryer cabinet}

Fresh Nipa leaves (approximately 3,000 pieces) were placed in the cabinet for drying for 4 hours as shown in Fig. 3. The relative humidity and temperature inside the cabinet were measured every hour using humidity meter (HTC2; China). In SDC, the leaves were dried and collected every hour to measure the humidity by using humidity analyzer (Sartorius MA150; Germany) and the color was measured by using colorimeter (Hunter lab, Konica; Japan).

The effect of heaters was then investigated in SDCH mode. This experiment was conducted in the similar manner as described for SDC. The dried leaves were further used to make Nipa bowls and kept for 13 weeks. The bacteria contamination was investigated through plate count agar (PCA) technique (AOAC, 2005).

The reduction of Nipa waste was also calculated by comparing waste amount before and after the implementation of solar dryer technology.

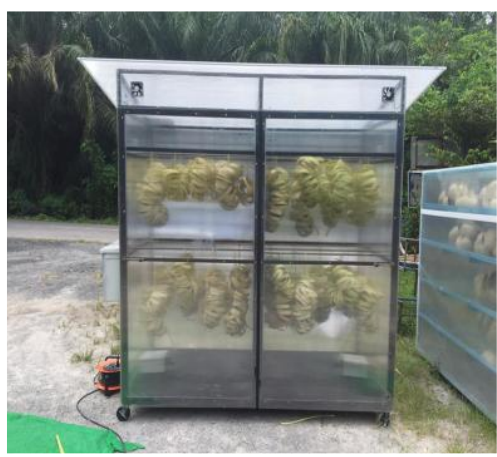

Fig. 3 Drying of Nipa leaves with solar dryer cabinet.

\section{RESULTS AND DISCUSSION}

\section{Performance of solar dryer cabinet}

The performance of the SDC and SDCH were evaluated and compared to SD method. Table 1 shows the change of temperature which was measured every hour. For SDC, the temperature increased from $40.8 \pm 2.1{ }^{\circ} \mathrm{C}$ to $57.2 \pm 0.4{ }^{\circ} \mathrm{C}$ within 4 hours and the heating rate was $4.1{ }^{\circ} \mathrm{C} / \mathrm{h}$. When the heaters of $\mathrm{SDCH}$ were turned on, the temperature increased up to $70.0 \pm 0.0{ }^{\circ} \mathrm{C}$ after operated for $4 \mathrm{~h}$. In this case, the heating rate was increased to about $78.0 \%\left(7.3^{\circ} \mathrm{C} / \mathrm{h}\right.$.). In SD method, the temperature fluctuated over the course of $4 \mathrm{~h}$ and the maximum temperature within the studied time was only $36.0 \pm 2.8^{\circ} \mathrm{C}$. Thus, the use of SDC and SDCH could increase the temperature and these were suitable for drying Nipa leaves.

Although SDCH gave the highest temperature, both SDC and SDCH were used, where the SDC the SDC was employed in the sunny day and the SDCH was used when there was less sunshine, to curtail electricity cost associated with the use of heaters. Thus, the drying of Nipa leaves could be performed continuously.

Relative humidity was measured in order to evaluate the performance of SDC, SDCH, and SD, as shown in Table 2. For SDC, the relative humidity was reduced from $40.0 \pm 2.0$ to $22.0 \pm 1.0 \%$ within 4 hours. The use of SDCH could further reduce the relative humidity from $40.0 \pm 1.0$ to $18.0 \pm 1.0 \%$ after 4 hours. For SD, the relative humidity was relatively high at $42.0 \pm 1.0 \%$.

Table 1. The temperatures measured by different drying methods.

\begin{tabular}{lccccc}
\hline \multirow{2}{*}{$\begin{array}{c}\text { Drying } \\
\text { Methods }\end{array}$} & \multicolumn{5}{c}{ Temperature $\left({ }^{\circ} \mathbf{C}\right)$} \\
\cline { 2 - 6 } & Starter & $\mathbf{1 ~ h r}$. & $\mathbf{2}$ hrs. & 3 hrs. & $\mathbf{4}$ hrs. \\
\hline SDC & $40.8 \pm 2.1^{\mathrm{b}}$ & $46.3 \pm 1.1^{\mathrm{b}}$ & $55.2 \pm 3.1^{\mathrm{b}}$ & $56.8 \pm 1.8^{\mathrm{b}}$ & $57.2 \pm 0.4^{\mathrm{b}}$ \\
SDCH & $41.0 \pm 2.1^{\mathrm{b}}$ & $53.8 \pm 1.7^{\mathrm{c}}$ & $70.0 \pm 0.0^{\mathrm{c}}$ & $70.0 \pm 0.0^{\mathrm{c}}$ & $70.0 \pm 0.0^{\mathrm{c}}$ \\
SD & $31.2 \pm 1.3^{\mathrm{a}}$ & $30.8 \pm 1.7^{\mathrm{a}}$ & $36.0 \pm 2.8^{\mathrm{a}}$ & $34.3 \pm 2.5^{\mathrm{a}}$ & $32.2 \pm 3.0^{\mathrm{a}}$
\end{tabular}

*Different characters in each column illustrated average comparison by method of Duncan's multiple range tests at $95 \%$ confidence interval, respectively. 
Table 2. Relative humidity measured in SDC, SDCH, and SD methods.

\begin{tabular}{lccccc}
\hline \multirow{2}{*}{$\begin{array}{c}\text { Drying } \\
\text { Methods }\end{array}$} & \multicolumn{5}{c}{ Relative Humidity (\%) } \\
\cline { 2 - 6 } & Starter & $\mathbf{1}$ hr. & $\mathbf{2}$ hrs. & $\mathbf{3}$ hrs. & $\mathbf{4}$ hrs. \\
\hline SDC & $40.2 \pm 2.0^{\mathrm{a}}$ & $40.0 \pm 2.0^{\mathrm{a}}$ & $31.1 \pm 2.0^{\mathrm{b}}$ & $26.0 \pm 1.0^{\mathrm{b}}$ & $22.0 \pm 1.0^{\mathrm{b}}$ \\
SDCH & $40.3 \pm 3.0^{\mathrm{a}}$ & $36.0 \pm 1.0^{\mathrm{a}}$ & $27.0 \pm 2.0^{\mathrm{a}}$ & $22.0 \pm 1.0^{\mathrm{a}}$ & $18.0 \pm 1.0^{\mathrm{a}}$ \\
SD & $40.0 \pm 1.0^{\mathrm{a}}$ & $52.0 \pm 3.0^{\mathrm{b}}$ & $41.0 \pm 1.0^{\mathrm{c}}$ & $35.0 \pm 2.0^{\mathrm{c}}$ & $42.0 \pm 1.0^{\mathrm{c}}$ \\
\hline
\end{tabular}

*Different characters in each column illustrated average comparison by method of Duncan's multiple range tests at $95 \%$ confidence interval, respectively.

\section{Characteristics of Nipa leaves processed in solar dryer cabinets}

Humidity of the Nipa leaves after drying with SDC and SDCH were investigated and the results are presented in Table 3. For SDC, the humidity of Nipa leaves was reduced from $69.0 \pm 0.8$ to $12.2 \pm 1.1 \%$ within 4 hours. The humidity removal rate was $14.2 \% / \mathrm{hr}$. The use of heater in SDCH decreased the humidity about $94.96 \%$ and the humidity removal rate was $16.6 \% / \mathrm{hr}$. These results could enhance the drying step of Nipa leaves and could dramatically increase the mass production of Nipa bowl. Unlike the SDC and SDCH, the traditional sun drying (SD) method could only reduce $78.3 \%$ humidity and the residual humidity was $20.1 \pm 0.3 \%$.

Table 3. The humidity of Nipa leaves after drying with different drying methods.

\begin{tabular}{lccccc}
\hline \multirow{2}{*}{$\begin{array}{c}\text { Drying } \\
\text { Methods }\end{array}$} & \multicolumn{5}{c}{ Humidity of Nipa leaves (\%) } \\
\cline { 2 - 6 } & Starter & $\mathbf{1}$ hr. & $\mathbf{2}$ hrs. & 3 hrs. & 4 hrs. \\
\hline SDC & $69.0 \pm 0.8^{\mathrm{a}}$ & $42.1 \pm 2.2^{\mathrm{b}}$ & $38.7 \pm 0.2^{\mathrm{b}}$ & $24.1 \pm 0.7^{\mathrm{a}}$ & $12.2 \pm 1.1^{\mathrm{a}}$ \\
SDCH & $69.9 \pm 0.5^{\mathrm{a}}$ & $38.7 \pm 0.6^{\mathrm{c}}$ & $15.2 \pm 0.8^{\mathrm{c}}$ & $4.8 \pm 0.7^{\mathrm{b}}$ & $3.5 \pm 0.9^{\mathrm{c}}$ \\
SD & $70.5 \pm 1.1^{\mathrm{a}}$ & $49.5 \pm 0.4^{\mathrm{a}}$ & $45.9 \pm 0.1^{\mathrm{a}}$ & $25.1 \pm 0.1^{\mathrm{a}}$ & $20.1 \pm 0.3^{\mathrm{a}}$ \\
\hline
\end{tabular}

* Different characters in each column illustrated average comparison by method of Duncan's multiple range tests at $95 \%$ confidence interval, respectively.

The heat production and the capacity to remove humidity of the solar dryer technology presented in this work are at par with the results of other reports. Table. 4 shows the comparison of solar dryer technology of this current work to other previous reports.

Table 4. Comparison of the solar dryer technology of this current work to other previous reports.

\begin{tabular}{lccl}
\hline Products & $\begin{array}{c}\text { Highest } \\
\text { Temp } \\
\left({ }^{\circ} \mathbf{C}\right)\end{array}$ & $\begin{array}{c}\text { Relative } \\
\text { Humidity } \\
(\%)\end{array}$ & \multicolumn{1}{c}{ References } \\
\hline Fish & 83.0 & - & Nambing et al., 2015 \\
Fish & 55.6 & 19.9 & Hubackova et al., 2014 \\
Meat & 48.6 & - & Jansawang, 2011 \\
Olive leaf & 40.0 & - & Bahloul et al., 2009 \\
Pegaga leaf & 56.0 & 36.0 & Yahya et al., 2004 \\
Nipa leaf & 70.0 & 18.0 & This current work \\
\hline
\end{tabular}

The color of the Nipa palm after the drying processes was investigated and shown in Fig. 4 The results showed that the color of the leaves was related to the color of the Nipa leaves. The color obtained from SDCH showed the highest $\mathrm{L}$ value indicating the highest brightness of the leaves. After 4 hours, the $\mathrm{L}$ value was $86.27 \pm 0.33$. For SDC, the L value was $80.10 \pm 0.99$ which was slightly lower than $\mathrm{SDCH}$. The color of fresh Nipa leaves and those after drying in solar drying cabinet were shown in Fig. 5. The color of the Nipa leaves processed by SDC and SDCH were accepted by the community to produce Nipa bowls.

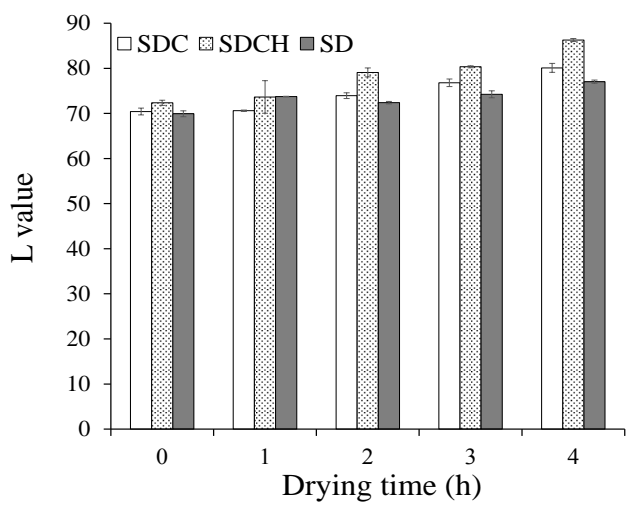

Fig. 4 The $L$ value of Nipa leaves processed with SDC, SDCH, and SD.

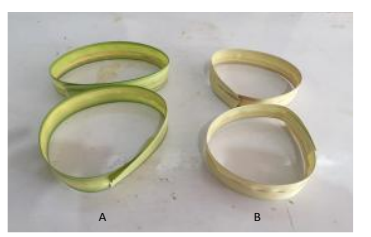

Fig. 5 (A) The color of fresh Nipa leaves and (B) the color of Nipa leaves after drying with solar dryer cabinet.

\section{Microbial contamination}

In the traditional method, the Nipa leaves are dried in direct sunlight in an open-air area. This method could not remove humidity effectively and the dried leaves are exposed to dust and microbial contamination. These drawbacks will affect the quality of the products directly. This problem was addressed by using SDC and SDCH where the leaves were dried in a closed system. The microbial contamination was tested with PCA method and the results are shown in Table 5.

As shown in Table 5, the microbial contaminations were $480 \pm 173$ and $463 \pm 112$ for SDC and SDCH, respectively. According to the regulation of the Department of Medical Sciences (DMSC), the microbiological quality criteria of food and food container is $10^{3}$ cfu/piece (DMSC, 2017). Therefore, the use of SDC and SDCH can reduce bacteria contamination effectively. In contrast, the bacteria contamination obtained from Nipa bowl with SD method had the highest contamination. Thus SDC and SDCH drying process could be used to replace the traditional SD method.

Table. 5 Total bacteria detected in Nipa bowl by different methods and stored for 1-3 weeks

\begin{tabular}{cc}
\hline Production Methods & Total Bacteria (cfu/piece) \\
\hline SDC & $480 \pm 173$ \\
SDCH & $463 \pm 112$ \\
SD & $95,000 \pm 40,414$ \\
\hline
\end{tabular}

\section{Economic evaluation of Nipa bowl production by using the SDC}

After the solar technology was implemented in the community, a follow-up assessment of the economics was evaluated. It was found that the income of the community increased. Based on traditional process, Ban Na Yod Tong Nipa Palm Leaf Handicraft can produce Nipa bowl to an average of 4,700 bowls per month (May-June 2017). After employing the technology, the capacity had increased within a period of nine months (July 2017-April 2018). In July 2017, the number of sold Nipa bowls were 8,780 pieces. The production capacity had increased continuously, especially in March 2018 with 27,000 pieces of Nipa bowls produced. The Nipa bowl production soared 3.5 times higher during the operation period, which was from July 2017 to April 2018. Based on this findings, approximately 170,000 pieces of Nipa bowls could be produced per year. This could generate income to about 5,171 USD per month. The enterprise's income will be distributed to 50 households of the group whose average income per household were about 102 USD a month. The potential of the production of Nipa bowl 
in the group both before and after installing the SDC in Ban Na Yod Tong Nipa Palm Leaf Handicraft is shown in Fig. 6

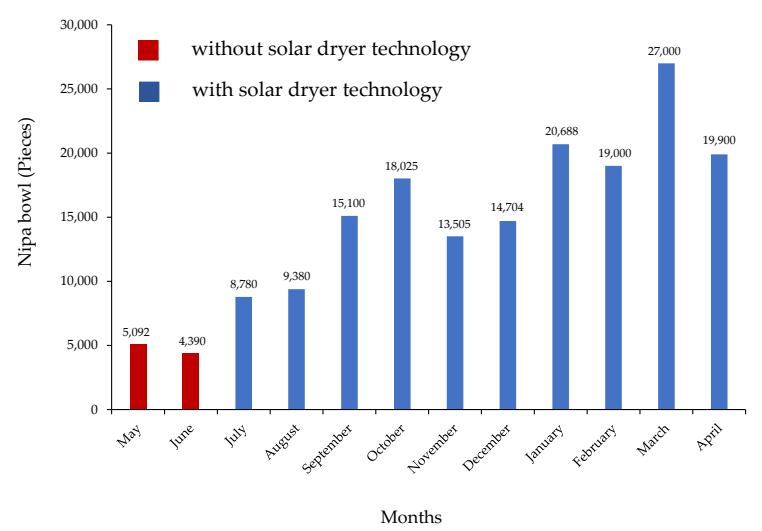

Fig. 6 The potential of the production of Nipa bowl at Ban Na Yod Tong Nipa Palm Leaf Handicraft from May 2017 to April 2018

From the knowledge transmission to the nearby community, a new group was founded. One of the examples is the group at Ban Tharue, Wang Won Sub-district, Kantang District. Prior to the installation of the solar dryer technology, this group used Nipa leaves only for the production of cigarette wrapping. Nowadays, with the current technology, the group can make more than 13,000 pieces of Nipa bowls. This advancement in production process generates the community's additional income of 4,266 USD or an average of 853 USD per month. The production of Nipa bowl in the Ban Tharue group after the installation of solar dryer technology is presented in Fig. 7.

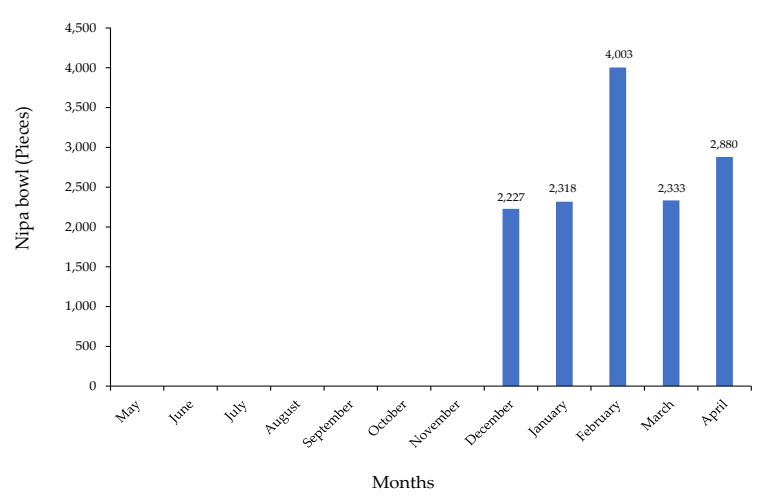

Fig. 7 The production of Nipa bowl at Ban Tharue group after receiving solar dryer technology from May 2017 to April 2018.

\section{Calculation of Nipa waste reduction}

Significantly, the use of solar dryer technology can reduce the Nipa waste. After the implementation of the technology, 183,000 pieces of Nipa bowls could be produced per year. If one Nipa frond $(0.1 \mathrm{~kg})$ could be used to produce $10 \mathrm{Nipa}$ bowls, then 18,000 fronds are needed to produce 183,000 bowls. This could reduce the Nipa waste about 1.83 tons.

\section{CONCLUSION}

Based on the integration of community-based research on the development of solar dryer technology, it was found that the technology provides more effective and satisfied performance in drying Nipa leaves. It can address the intermittent nature of sun drying method as it depends on the climate conditions. Moreover, the efficiency of Nipa leaves production was increased and could produce Nipa leaves all year round. Furthermore, it can create an undeniably positive impact on local economy. The development of the incubator efficiency increases Nipa bowl production to up 500 bowls generating 155 USD per production cycle.

In addition, the production of dried Nipa leaves which used solar dryer technology has better quality. Also, it reduces the risk of bacterial contamination which is lower than the regulation set by the Department of Medical Sciences of Thailand. Importantly, the products can reduce the use of plastic containers and the environmental problems. Nowadays, people are aware of their health and harmful effects of polystyrene foam. To avoid the hazardous chemical substances, they prefer to use more of eco-friendly food packaging in their daily life. Thus, Nipa bowl products produced from natural sources can fulfill this requirement. Fig. 8 shows the use of Nipa bowls as beverage containers in green market.

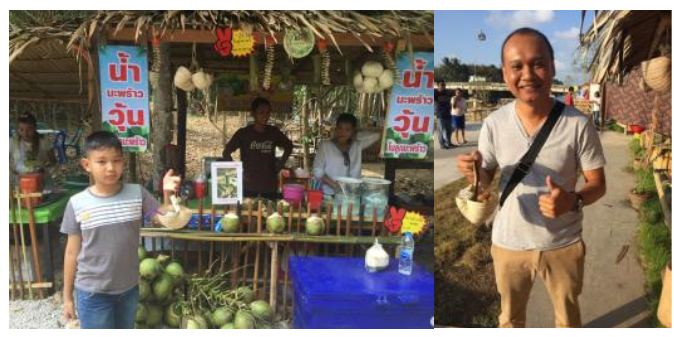

Fig. 8 The use of Nipa product produced from this work.

\section{ACKNOWLEDGEMENTS}

This work was supported by Rajamangala University of Technology Srivijaya Research Fund. The authors would like to express our deep gratitude to the group members of Ban $\mathrm{Na}$ Yod Tong Nipa Palm Leaf Handicraft. This work would not have been possible without their assistance and cooperation.

\section{REFERENCES}

AOAC (2005). Official method of analysis. 18th Edition, Association of Officiating Analytical Chemists, Washington D. C.

Bahloul, N., Boudhrioua, N., Kouhila, M., Kechaou, N. (2009). Effect of convective solar drying on colour, total phenols and scavenging activity of olive leaves (Olea europaea L). Int. J. Food Sci. Technol. 44(12), 25612567.

Belessiotis, V., Delyannis, E. (2011). Solar drying, Solar Energy, 85(8), 1665 1691.

Carandang, M. G., Camacho, L.D., Carendang, A.P., Camacho, S.C., Gevaa, D. T., Rebugio, L. L., Youn, Y. C. 2009. Sustainable thatching materials production from Nipa (Nypa fruticans) in Bohol, Philippines. Forest. Sci. Technol. 5(1), 17-22.

DMSC. 2017. Microbiological quality criteria food and food containers Issue 3 . [Online]. Available: http://www.dmsc.moph.go.th/dmscnew/news_detail. php?cid=2\&id=1646 [2018, April 20].

Hamdi, I., Kooli, S., Elkhadraoui, A., Azaizzia, Z., Abdelhamid, F. (2018). Experimental study and numerical modeling for drying grapes under solar greenhouse. Renew. Energ. 127, 936-946.

Hossain, F., and Islam, A. 2015. Utilization of mangrove forest plant: Nipa palm (Nypa fruticans Wurmb.). Am. J. Agric. For. 3(4), 156-160.

Hubackova, A., Kucerova, I., Chrun, R., Chaloupkova, P., Banout, J. (2014). Development of solar drying model for selected Cambodian fish species. Sci. World. J. 2014, Art. ID 439431, 1-10.

Jansawang, W. Meat products drying with a compact solar cabinet dryer. (2017). International Conference on Alternative Energy in Developing Countries and Emerging Economies 2017 (AEDCEE), 25-26 May 2017, Bangkok, Thailand Energy Procedia. 138, 1048-1054.

Nambing, M., Maikasuwa, G. (2015). Construction of domestic solar fish dryer. IOSR J. Appl. Phy. 7(5), 9-13.

Okugbo, O. T., Usunobun, U., Esan, A., Adegbegi, J. A., Oyedeji, J. O., Okiemien, C.O. (2012). A review on Nipa palm as a renewable energy source in Nigeria. Res J Appl Sci Eng Tech. 4(15), 2367-2371.

Onibogi, I. O., Sobowale, S. S., Ezekoma, O. S. (2012). Design, construction and evaluation of a small scale solar dryer. Eng. Appl. Sci. 4, 8-21.

Ronaldo, O. O., Nomalina, P. U. (2014). Improving the quality of Nipa (Nypa Fructicans) wine. Asia Pacific J. Educ. Art. Sci. 1, 24-27.

Sharma, A., Chen, C.R., Lan, N. V. (2009), Solar-energy drying systems: A review, Renewable Sustainable Energy Rev. 13(6-7), 1185-1210.

Tamunaidua, P., Matsui, N., Okimori, Y., Saka, S. (2013). Nipa (Nypa fruticans) sap as a potential feedstock for ethanol production. Biomass Bioenerg. 52 , 96-102.

Yahya, M., Othman, M. Y., Sopian, K., Daud, W. R. W., Yatim, B. (2004). Quality of Pegaga leaf dried in a solar assisted dehumidification drying system. Proceeding of the 14th International Drying Symposium (IDS 2004). Sao Paulo, Brazil. 22-24 August, vol. B, pp. 1049-1054. 